\title{
Extraction of antioxidant components from peanut skins
}

\author{
By Valeria Nepote ${ }^{1}$, Nelson R. Grosso ${ }^{* 2}$ and C. A. Guzman ${ }^{1}$ \\ ${ }^{1}$ Instituto de Ciencia y Tecnología de los Alimentos, FCEFyN (UNC), IMBIV (CONICET), \\ Av. Vélez Sársfield 1600.5000 Córdoba, Argentina. \\ ${ }^{2}$ Química Biológica, FCA (UNC), IMBIV (CONICET), Avda. Valparaíso s/n, CC 509, \\ 5000 Córdoba, Argentina. e-mail: nrgrosso@agro.uncor.edu.
}

\section{RESUMEN}

\section{Extracción de componentes antioxidantes del tegu-} mento seminal de maní.

El objetivo del trabajo fue extraer sustancias antioxidantes del tegumento de las semillas de maní usando diferentes tipos de solventes y determinar la actividad antioxidante de los extractos. Extractos metanólicos, etanólicos, acetónicos y acuosos fueron preparados desde tegumento de maní desengrasado y sin desengrasar. Sobre los extractos se determinaron los contenidos de materia seca y fenoles totales, actividad secuestrante de radicales libres y la actividad antioxidante sobre aceite de girasol. El tegumento de maní usado en este trabajo tuvo la siguiente composición porcentual: $16.60 \%$ de aceite, $12.32 \%$ de proteínas, $2.83 \%$ de cenizas y $69.8 \%$ de otros componentes. Alto contenido de materia seca se encontró en extractos metanólicos $(17.11 \%)$, etanólicos (17.70\%) y acetónicos (18.54\%) de tegumentos sin desengrasar. Menor contenido de materia seca mostró el extracto acetónico de tegumento desengrasado que él de el tegumento no desengrasado. Alto contenido de fenoles totales fue detectado en extractos metanólicos $(158.6 \mathrm{mg} / \mathrm{g})$ y etanólicos $(144.1 \mathrm{mg} / \mathrm{g})$ del tegumento de maní desengrasado. Además estos dos últimos extractos a concentraciones de $1 \mu \mathrm{g} / \mathrm{mL}$ tuvieron una actividad secuestrante de radicales libres que fueron de $32.59 \%$ y $31.5 \%$, respectivamente. Todos los extractos $(0.05 \% \mathrm{p} / \mathrm{p})$ en aceite de girasol presentaron actividad antioxidante. La actividad antioxidante de los extractos fue menor que la que presentó el BHT.

PALABRAS-CLAVE: Actividad antioxidante - Arachis hypogaea - Compuestos fenólicos - Maní.

\section{SUMMARY} skins.

Extraction of antioxidant components from peanut

The objective of this work was to extract antioxidant components from peanut skins using different solvents and to determine antioxidant activity of the extracts. Methanolic, ethanolic, acetonic and aqueous extracts were prepared from defatted and non defatted peanut skins. Total dry matter content and total phenolic content, radical-scavenging activity and antioxidant activity in sunflower oil were determined from the extracts. The peanut skins used in this work had the following proximate composition: $16.60 \%$ oil, $12.32 \%$ protein, $2.83 \%$ ash and $69.8 \%$ other components. High content of total dry matter was found in methanolic $(17.11 \%)$, ethanolic $(17.70 \%)$ and acetonic $(18.54 \%)$ extracts from non defatted peanut skins. The acetonic extract from defatted peanut skins had lower dry matter extraction than the non defatted peanut skin extract. High content of total phenolics was detected in methanolic $(158.6 \mathrm{mg} / \mathrm{g})$ and ethanolic $(144.1 \mathrm{mg} / \mathrm{g}$ ) extracts from deffated peanut skins. These last two extracts in concentration of $1 \mu \mathrm{g} / \mathrm{mL}$, the radical-scavenging activities were $32.59 \%$ in methanolic extract and $31.5 \%$ in ethanolic extract. All extracts $(0.05 \% \mathrm{w} / \mathrm{w})$ in sunflower oil showed antioxidant activity. This antioxidant activity from the extracts was lower than that activity from BHT.

KEY-WORDS: Antioxidant activity - Arachis hypogaea - Peanut - Phenolic compounds.

\section{INTRODUCTION}

The addition of antioxidants to foods is one of the most effective means for retarding fat oxidation. It has become increasing popular as a method for increasing shelf life of food products and improving the stability of lipids and lipid-containing foods, thus preventing loss of sensory and nutritional quality. Synthetic antioxidants, such as butylated hydroxyanisole (BHA), butylated hydroxytoluene $(\mathrm{BHT})$ and propyl gallate (PG), are used in many foods to prevent rancidity. Because of growing concern for the potential health hazards of synthetic antioxidants. One example is the work from lto et al. (1982) that reported BHA to be carcinogenic in animal experiments. There is renewed interest in the increased use of naturally occurring antioxidants. Because they occur in nature and in many cases are derived from plant sources, natural antioxidant are presumed to be safe. For these reasons, many studies have been carried out to find out potential antioxidant activity compounds from natural sources (St. Angelo, 1996).

Several studies on the antioxidant components from peanut hulls have been performed. Duh et al. (1992) extracted and identified antioxidant components. Yen et al. (1993) described the relationship between antioxidant activity of methanol extracts and maturity of peanut hulls and reported that the total phenolic content increased with maturity. Yen and Duh (1994) reported a marked radical-scavenging effect of methanolic extracts of peanut hulls and these authors in 1995 (Yen and Duh, 1995) also found that the Spanish peanut cultivar had higher total phenolic content than other peanut cultivars. Finally, Duh and Yen (1997) reported that antioxidant compounds of methanolic extracts from peanut hulls had antioxidant efficacy in soybean and peanut oils. 
However, antioxidant activity in vegetable oil of compounds from peanut skins have not been deeply investigated yet. Only, a preliminary report was performed on antioxidant activity of methanolic extracts from peanut skins (Nepote et al., 2000).

Peanut skins are a waste from blanched processing of peanut kernels. In Argentina, peanut skins are sometimes used to feed cattle however, their value could be increased if other more valuable uses could be found. The objective of this work was to extract antioxidant components from peanut skin using different solvents, and to determine the antioxidant activity of the extracts.

\section{EXPERIMENTAL}

\subsection{Materials}

Peanut skins from Argentinean peanut (cv Florunner, 1999 crop year) were obtained for blanched and were provided for the Company "Lorenzati, Ruesch y Cia", Ticino, Córdoba, Argentina in July, 1999. The peanut skins were kept in a sealed plastic bag and stored at $4{ }^{\circ} \mathrm{C}$ until used.

\subsection{Proximate composition of peanut skins}

Three samples of dry peanut skins were examined for oil, protein and ash. For fat percentage, each sample was extracted for $16 \mathrm{~h}$ with petroleum ether (boiling range $30-60^{\circ} \mathrm{C}$ ) in a Soxhlet apparatus. Oil percentage was determined by weight difference. Ash was performed by incineration in a muffle furnace at $525^{\circ} \mathrm{C}$ (AOAC, 1980 method 27.009). The nitrogen content was estimated by the Kjeldahl method (AOAC, 1980 method 27.007) and converted to protein percentage using the conversion factor of 6.25 . The remaining components were called other components and were estimated using the formula: Other components $=100 \%-(\%$ protein $+\%$ oil $+\%$ ash). All determinations were run in triplicate and averaged.

\subsection{Extraction of antioxidant components from peanut skins}

Antioxidant compounds were extracted from peanut skins using different extraction solvents: methanol (Cicarelli, Santa Fé, Argentina), ethanol (Dalton, Godoy Cruz, Mendoza, Argentina), acetone (Cicarelli, Santa Fe, Argentina), distilled water. The following extracts were produced: methanolic extract $(\mathrm{ME})$, ethanolic extract (EE), acetonic extract (KE), and aqueous extract (AE). To obtain each extract, the peanut skins $(10 \mathrm{~g})$ were extracted with one extraction solvent $(100 \mathrm{~mL})$ during 24 hours by maceration at room temperature in a dark room. The extract was filtered and the residue was extracted again under the same conditions. The combined filtrate was evaporated to dryness in vacuo in a rotary evaporator (Buchi R 110, Frawil, Switzerland) at $35^{\circ} \mathrm{C}$. The percentage of dry extracted matter was determined on dry peanut skin basis.

The defatted peanut skins were obtained for two extraction with $\mathrm{n}$-hexane $(50 \mathrm{~mL})$ from peanut skins $(5 \mathrm{~g})$ during 12 hours each one at room temperature. All extraction were run in triplicate and averaged. The same procedure used to prepare extracts from non defatted peanut skins was performed to prepare extracts from defatted peanut skins. The following extracts were produced from defatted peanut skins: methanolic extract (dME), ethanolic extract (dEE), acetonic extract (dKE), and aqueous extract (dAE).

\subsection{Determination of total phenolic compounds}

The total phenolic compounds present in the peanut skins were determined spectrophotometrically using the Folin-Ciocalteu method according to Waterman and Mole (1994). Peanut skin extract (3.0 $\mathrm{mg}$ ) was dissolved in $10 \mathrm{~mL}$ methanol. This methanolic solution $(0.1 \mathrm{~mL})$ was transferred into a $10 \mathrm{~mL}$ volumetric flask. Deionized water $(8.4 \mathrm{~mL})$ and $0.5 \mathrm{~mL}$ Folin-Ciocalteu reagent (Anedra, San Fernando, Buenos Aires, Argentina) were added, and the contents of the flask were mixed thoroughly. After $1 \mathrm{~min}, 1 \mathrm{~mL} \mathrm{Na} \mathrm{CO}_{3}$ solution $(20 \mathrm{~g} / 100 \mathrm{~mL})$ was added and finally quantified to $10 \mathrm{~mL}$ with deionized water. After 1 hour, absorbance was measured with a spectrophotometer (Spectronic 21, Bausch and Lomb, USA) at $760 \mathrm{~nm}$. The concentration of total phenolic compounds in extracts of peanut skins was determined by comparison with the absorbance of phenol (Merk, Darmstadt, Germany) as standard used at different concentration. All tests were run in triplicate, and analyses of all samples were run in duplicate and averaged.

\subsection{Determination of radical-scavenging activity}

The radical-scavenging activity was determined using diphenyl picryl hydrazyl radical (DPPH) (Aldrich, Milwaukee, WI, USA) according to Joeux et al. (1995). 8, 37.5 and $75 \mu \mathrm{L}$ methanolic solution of peanut skin extract $(300 \mu \mathrm{g} / \mathrm{mL})$ were added to a 1.5 $\mathrm{mL}$ methanolic solution of DPPH radical $(20 \mu \mathrm{g} / \mathrm{mL})$ to get final concentration of 1,5 and $10 \mu \mathrm{g} / \mathrm{mL}$, respectively. The mixture was shaken vigorously and left to stand for $5 \mathrm{~min}$. The absorbance of the resulting solution was measured at $517 \mathrm{~nm}$ with a spectrophotometer (Spectronic 21, Bausch and Lomb, USA). The radical-scavenging activity was calculated using the formula: \% inhibition $=[1-$ (absorbance of DPPH and sample - absorbance of sample) / absorbance of DPPH] x 100. All tests were 
run in triplicate, and analyses of all samples were run in duplicate and averaged.

\subsection{Determination of antioxidant activity}

The antioxidant activity in sunflower oil of the peanut skin extracts was determined according to the procedure described by Duh and Yen (1997). In an open $50-\mathrm{mL}$ beaker, $3 \mathrm{mg}$ extract was mixed with $6 \mathrm{~g}$ oil $(0.05 \% \mathrm{w} / \mathrm{w})$. Each treatment was placed in an oven at $60^{\circ} \mathrm{C}$. The peroxide value of each treatment were determined by AOAC (1980) method 28.022 at intervals during 4 days of storage. $\mathrm{BHT}(0.02 \%)$ was used like a reference to compare antioxidant activity. All tests were run in triplicate, and analyses of all samples were run in duplicate and averaged.

\subsection{Statistical analysis}

Statistical analyses were conducted with the InfoStat software package (InfoStat software, version Beta, 1999, Facultad de Ciencias Agropecuarias, Universidad Nacional de Córdoba, Córdoba, Argentina) of replicate test data. Analysis of variance were performed by ANOVA procedures. Significant differences $(\alpha=0.05)$ between means were determined by LSD tests. Regression analysis was performed to determine the effect of time on the antioxidant activity of extracts on sunflower oil. Second order polynomial regression equation was obtained for each treatment: $\mathrm{y}=\mathrm{Ax^{2 }}+\mathrm{Bx}+\mathrm{C}$, where $\mathrm{y}=$ Peroxide value $\left(\mathrm{meqO}_{2} / \mathrm{kg}\right), \mathrm{x}=$ time (days).

\section{RESULTS AND DISCUSSION}

\subsection{Proximate composition}

Table I shows the proximate composition of peanut skins. Woodroof (1983) reported $12.68 \%$ protein and oil $11.76 \%$ oil. Oil content was higher in peanut skins used in this work. This is because the industrial blanched process produces a lot of particles of peanut flour that are mixtured with peanut skins. These particles could have increased the oil content in the used material.

\subsection{Yields of extraction and total phenolic contents}

The dry matter extraction percentages of methanolic, ethanolic, acetonic and aqueous extracts are shown in Table II. ME, EE, KE, dME and $\mathrm{dEE}$ had higher extraction percentages. These extracts showed no significant differences $(\alpha=0.05)$ among them in their percentage of extraction. $\mathrm{AE}$ and $\mathrm{dAE}$ had lower percentages than the other extracts. The extraction percentages of ME, EE, AE,
Table I

Proximate composition (wt\%) of peanut skins

\begin{tabular}{ll}
\hline & Percentage $^{\mathrm{a}}$ \\
\hline Oil & $16.60 \pm 0.77$ \\
Protein $(\mathrm{N} \times 6.25)$ & $12.32 \pm 0.21$ \\
Ash & $2.83 \pm 0.10$ \\
Other components & $69.8 \pm 1.02$ \\
\hline
\end{tabular}

a Expressed on dry matter basis.

Table II

Extraction percentages (wt\%) of antioxidant components and phenolic total contents $(\mathrm{mg} / \mathrm{g})$ of the extracts from peanut skins using different solvents

\begin{tabular}{lll}
\hline Extract $^{\mathrm{a}}$ & Extraction percentage $^{\mathrm{b}}$ & Phenolic total content $^{\mathrm{b}}$ \\
\hline $\mathrm{ME}$ & $17.9(\mathrm{~cd}) \pm 0.6$ & $148.7(\mathrm{~d}) \pm 3.6$ \\
$\mathrm{EE}$ & $18.5(\mathrm{~cd}) \pm 0.2$ & $114.8(\mathrm{c}) \pm 5.9$ \\
$\mathrm{KE}$ & $19.4(\mathrm{de}) \pm 0.6$ & $61.4(\mathrm{a}) \pm 1.4$ \\
$\mathrm{AE}$ & $9.9(\mathrm{a}) \pm 0.1$ & $58.5(\mathrm{a}) \pm 2.4$ \\
$\mathrm{dME}$ & $17.1(\mathrm{~cd}) \pm 0.9$ & $165.6(\mathrm{~d}) \pm 16.2$ \\
$\mathrm{dEE}$ & $16.2(\mathrm{c}) \pm 1.1$ & $150.4(\mathrm{~d}) \pm 9.1$ \\
$\mathrm{dKE}$ & $13.1(\mathrm{~b}) \pm 0.1$ & $65.5(\mathrm{a}) \pm 1.8$ \\
$\mathrm{dAE}$ & $10.0(\mathrm{a}) \pm 0.3$ & $90.7(\mathrm{~b}) \pm 1.1$ \\
\hline
\end{tabular}

a Abbreviations: $\mathrm{ME}=$ Methanolic extract, $\mathrm{EE}=$ Ethanolic extract, $\mathrm{KE}=$ acetonic extract, $\mathrm{AE}=$ Aqueous extract. The reference letter add "d" when it is from defatted peanut skins.

b Means followed by the same letter within each column are not significantly different at $\alpha=0.05$.

dME, dEE and $d A E$ were not significantly different. $K E$ had a higher percentage of extraction than dKE.

The total phenolic contents of the extracts are also shown in Table II. ME, EE, dME and dEE had higher $(\alpha=0.05)$ total phenolic contents than KE, $\mathrm{AE}, \mathrm{dKE}$ and $\mathrm{dAE}$. The phenolic contents of ME and KE were not significantly different $(\alpha=0.05)$ than those of $\mathrm{dME}$ and $\mathrm{dKE}$, respectively. However, the phenolic contents of $\mathrm{dEE}$ and $\mathrm{dAE}$ were higher than the phenolic contents of $E E$ and $A E$, respectively. Duh et al. (1992) reported $41.8 \mathrm{mg}, 19.9 \mathrm{mg}$ and 7.3 mg total phenolics per $g$ peanut hulls using methanol, ethanol and acetone as extraction solvents, respectively. In this work, the contents of total phenolic were higher than $50 \mathrm{mg}$ per g peanut skins in all extraction solvents. Particularly, methanolic extract had more than $150 \mathrm{mg}$ per $\mathrm{g}$ defatted peanut skins. These results indicate that peanut skins could be a higher source of phenolic compounds and natural antioxidant components than peanut hulls. 


\subsection{Radical-scavenging activity}

The scavenging activity of the extracts on the DPPH radical is shown in Fig. 1. The scavenging activity between 5 and $10 \mu \mathrm{g} / \mathrm{mL}$ extracts were not significantly different $(\alpha=0.05)$. Extracts of $1 \mu \mathrm{g} / \mathrm{mL}$ showed a significant difference with respect to 5 and $10 \mu \mathrm{g} / \mathrm{mL}$ extracts. The concentration of $1 \mu \mathrm{g} / \mathrm{mL}$ in dME y dEE showed scavenging activity of $32.59 \%$ and $31.5 \%$, respectively. Between extracts of the same solvent obtained from peanut skins and defatted peanut skins were not significantly different. The radical-scavenging activity of ME, EE, dME and $\mathrm{dEE}$ in all studied concentrations were higher followed by the radical-scavenging activity of water and acetone extracts. Yen and Duh (1994) found radical-scavenging activity of $89.3 \%$ inhibition in $1500 \mu \mathrm{g} / \mathrm{mL}$ methanolic extract from peanut hulls. These authors determined radical-scavenging activity by DPPH method. The same procedure was used in this work. In this work, the percentages of inhibitions were higher of $93 \%$ in methanolic, ethanolic and aqueous extracts of $10 \mu \mathrm{g} / \mathrm{mL}$ indicating that peanut skin extracts could have a higher radical-scavenging activity than the extracts from peanut hulls.

Phenolic extacts from other plants also showed antioxidant activity. The scavenging-activity of Cryptocaria alba, Prosopis tamarugo, Discorerea bridgesii and Sanicula graveolens were between $1-10 \%$ in $10 \mu \mathrm{g} / \mathrm{mL}$ extracts (Schemeda-Hirschmann et al. 1999). Crude polyphenol fraction $(5 \mu \mathrm{g} / \mathrm{mL})$ from carob pods had $13 \%$ of inhibition activity (Kumazawa et al., 2002). Pomegranate showed 46\% inhibition activity (Singh et al., 2002). Phenolic extract $(6.25 \mu \mathrm{g} / \mathrm{mL})$ of Cedrus deodora had $15 \%$ of inhibition activity. In mushrooms extracts, this activity was found (Mau et al., 2001).

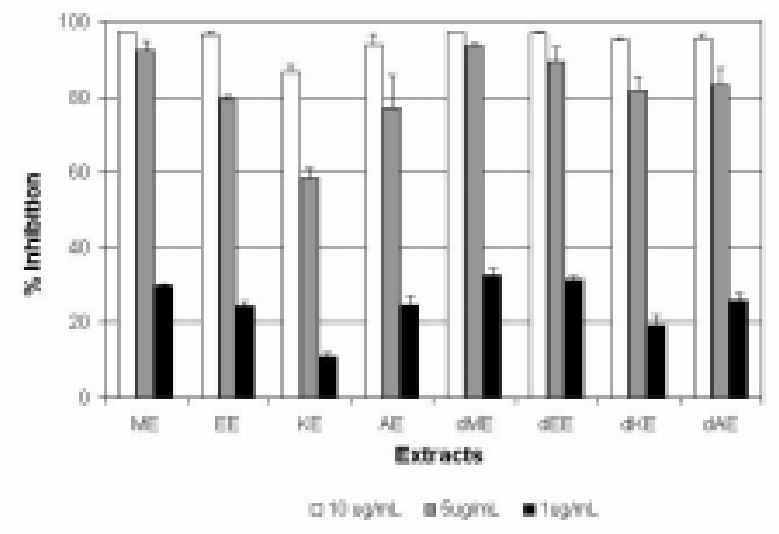

Figure 1

Radical-scavenging activity of the extracts from peanut skins. $\mathrm{ME}=$ Methanolic extract, $\mathrm{EE}=$ Ethanolic extract, $\mathrm{KE}=$ acetonic extract, $A E=$ Aqueous extract. The reference letter add " $d$ " when it is from defatted peanut skins.

\subsection{Antioxidant activity in sunflower oil}

The peroxide values was used to evaluate the oxidation of the sunflower oil. Therefore the antioxidant activity is when the sunflower oil develops a lower peroxide value along time. The experiment of antioxidant activity in sunflower oil was performed using only extracts from non defatted peanut skins due to radical-scavenging activity between extracts of the same solvent from peanut skins and defatted peanut skins did not show significant differences.

The peroxide values of control sunflower oil and sunflower oil with extracts $(0.05 \% \mathrm{w} / \mathrm{w})$ and BHT $(0.02 \% \mathrm{w} / \mathrm{w})$ storage in accelerated oxidation condition at $60{ }^{\circ} \mathrm{C}$ are shown in Fig. 2. Regression equation were used. The coefficient of the second order polynomial equations of regression study are presented in Table III. The adjusted $R^{2}$ for each regression equation was higher than 0.80 . All extracts were added at $0.05 \%$ in sunflower oil and showed antioxidant activity. The peroxide values in control sunflower oil were significantly higher $(\alpha=$ 0.05 ) at days 2, 3, 4 and 5 than those in sunflower oil with any extract or BHT. Significant differences $(\alpha=$ 0.05 ) in the antioxidant activity among extracts were not found but this antioxidant activity of the extracts was significantly lower than that from BHT $(0.02 \%)$. Duh and Yen (1997) reported similar antioxidant activity of methanolic extract from peanut hulls in soybean oil.

\section{CONCLUSION}

Methanolic, ethanolic and acetonic extracts in non defatted peanut skins showed higher percentage of extraction than the aqueous extract while that methanolic and ethanolic had higher extraction percentage in defatted peanut skins than

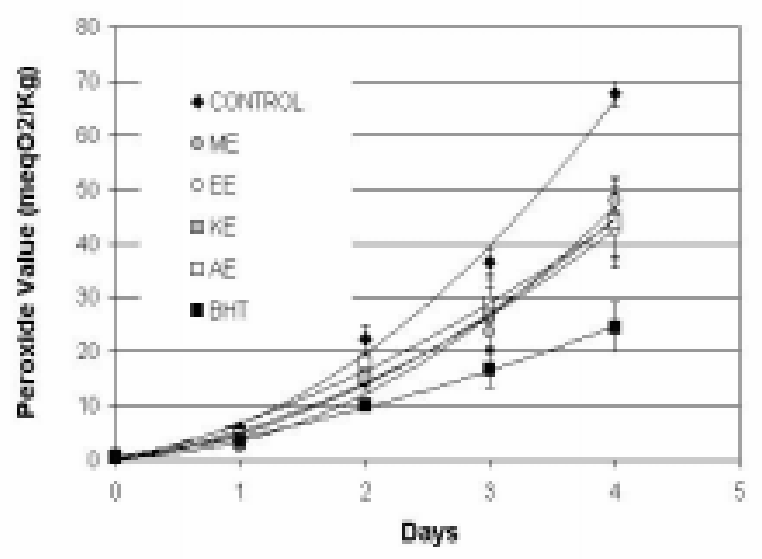

Figure 2

Peroxide value of sunflower oil with $0.05 \%$ extracts from peanut skins and $0.02 \%$ butylated hydrotoluene $(\mathrm{BHT})$ during storage at $60^{\circ} \mathrm{C} \cdot \mathrm{ME}=$ Methanolic extract, $\mathrm{EE}=$ Ethanolic extract, $\mathrm{KE}=$ acetonic extract, $\mathrm{AE}=$ Aqueous extract. 
Table III

Parameter estimates from regression analysis using second order polynomial equation $\left(y=A x^{2}+B x+C\right)$ in the study of antioxidant activity of the extract on sunflower oil

\begin{tabular}{ccccc}
\hline Extract $^{\mathrm{a}}$ & A & B & C & Adjusted $\mathbf{R}^{2}$ \\
\hline Control & 3.484 & 2.505 & 0.709 & 0.95 \\
$\mathrm{ME}$ & 2.897 & -0.027 & 0.635 & 0.91 \\
$\mathrm{EE}$ & 1.765 & 3.571 & 0.042 & 0.84 \\
$\mathrm{KE}$ & 2.101 & 2.713 & 0.071 & 0.83 \\
$\mathrm{AE}$ & 1.387 & 5.545 & -0.166 & 0.80 \\
$\mathrm{BHT}$ & 0.713 & 3.276 & 0.211 & 0.81 \\
\hline
\end{tabular}

a Abbreviations: $\mathrm{EM}=$ Methanolic extract, $\mathrm{EE}=$ Ethanolic extract, $\mathrm{KE}=$ acetonic extract, $\mathrm{AE}=$ Aqueous extract

acetonic and aqueous extracts. Methanolic and ethanolic extracts were greater in total phenolic compounds that are possible antioxidant components from the extracts. Therefore, methanolic and ethanolic extracts had higher inhibition percentages of radical-scavenging activity. However, the antioxidant activity in sunflower oil did not show significant difference among extracts.

The results of this research indicate that peanut skins from industrial blanched process could be an important sources of antioxidant compounds that can be well extracted using methanol or ethanol as solvents of extraction.

\section{ACKNOWLEDGMENT}

We thank CONICET and SECYT-UNC for support this research and the company "Lorenzati, Ruesch y Cia." for the provision of peanut skins.

\section{REFERENCES}

AOAC (1980).- "Official Methods of Analysis", 13th ed. Association of Official Analytical Chemists.-W. Horwithz (Ed.). Washington, D. C., USA.

Duh, P. D., Yeh, D. B. and Yen, G. C (1992)._-"Extraction and Identification of an Antioxidative Component from Peanut Hulls".- J. Am. Oil Chem. Soc. 69, 814-818.

Duh, P. D. and Yen, G. C (1997).-_"Antioxidant Efficacy of Methanolic Extracts of Peanut Hull in Soybean and Peanut".- Oil. J. Am. Oil Chem. Soc. 74, 745-748.

Ito, N., Hagiwara, A., Shibata, M., Ogiso, T. and Fukushima, S. (1982).- "Induction of Squamous Cell Carcinoma in the Forestomack of F334 Rats Treated with Butylated Hidroxyanisole".-Gann 73, 332-334.

Joyeux, M., Lobstein, A., Anton, R. and Mortier, F. (1995).- "Comparative antilipoperoxidant, antinecrotic and scavenging properties of terpenes and biflavones from Gingko and some flavonoids".-Planta Medica 61, 126-129.

Kikuzaki, H. and Nakatani, N. (1989).- "Structure of a new antioxidative phenolic acid from oregano".-Agric. Biol. Chem. 53, 519-524.

Kramer, R. E (1985).-_Antioxidants in clove”.-J. Am. Oil Chem. Soc. 62, 111-113.

Kumazawa, S., Taniguchi, M. Suzuki, Y., Shimura, M., Kwon, M. and Nakayama, T. (2002).--"Antioxidant activity of poliphenols in carob pods".-J. Agric. Food Chem. 50, 373-377.

Lea, C. H. (1958).- "Some nutritional and allied problems confronting the food manufacturer: Technological aspects of antioxidants".-J. Sci. Food Agric. 9, 621-632.

Mau, J. L., Chao, G. R. and Wu, K. T. (2001)._-"Antioxidant properties of methanolic extracts from several ear mushrooms".- J. Agric. Food Chem. 49, 5461-5467.

Nepote, V., Grosso, N. R. and Guzmán, C. A. (2000)."Antioxidant activity of methanolic extracts from peanut skin".- Molecules 5, 487-488.

Schmeda-Hirschmann, G., Razmilic, I., Gutierrez, M. I. and Loyola, J. L. (1999).-"Proximate composition and biological activity of food plants gathered by chilean amerindians".- Economy Botany 53, 177-187.

Singh, R. P., Chidambara, K. N. and Jayaprakasha, G. K. (2002).- - "Studies on the antioxidant activity of pomegranate (Punica granatum) peel and seed extracts using in vitro models".-J. Agric. Food Chem. $50,81-86$.

St. Angelo, A. J. (1996).- "Lipid oxidation in foods"..-Critical Reviews in Food Science and Nutrition 36, 175-224.

Tiwari, A. K., Srinivas, P. V., Kumar, S. P. and Rao, J. M. (2001).- "Free radical scavenging active components from Cedrus deodora"..-J. Agric. Food Chem. 49, $4642-4645$.

Waterman, P.G.and Mole S. (1994).- "Extraction and Chemical Quantification" in "Methods in Ecology: Analysis of Phenolic Plant Metabolites", 84-89.-J. H. Lawton and G. E. Likens (Eds.). Blackwell Scientific Publications, London, UK.

Woodroof, J. G. (1983)._-"Composition and Nutritive Value of Peanuts" in "Peanuts, Production, Processing, Products", 165-180, 3th ed. Avi Publishing Company, Inc., Westport, Connecticut, USA.

Yen, G. C. and Duh, P. D. (1994).- "Scavenging effect of methanolic extracts of peanut hulls on free-radical and active-oxigen species".-J. Agric. Food Chem. 42, 629-632.

Yen, G. C. and Duh, P. D. (1995)._-“Antioxidant activity of methanolic extracts of peanut hulls from various cultivars".- J. Am. Oil Chem. Soc. 72, 1065-1067.

Yen, G. C., Duh, P. D. and Tsai, C. L. (1993).--"Relationship between antioxidant activity and maturity of peanut hulls".- J. Agric. Food Chem. 41, 67-70. 